\title{
IMPLEMENTATION OF RURAL DEVELOPMENT PROGRAMMES IN JAMMU AND KASHMIR
}

\section{Younis Ahmad Sheikh}

\author{
Research Scholar \\ M.P. Institute of Social Science Research, Ujjain \\ Email:unisrashid@ymail.com
}

DOI: https://doi.org/10.18196/jgpp.5191

Article Info

Article history:

Received 26 Jan 2018

Revised 15 Feb 2018

Accepted 15 Mar 2018

\section{ABSTRACT}

Rural development is a holistic concept encompassing both natural and human resources development in an integrated manner. It aims at increasing the opportunities of all rural people in respect of health, knowledge, and skill development, income and participation in decision making and creating a conducive environment in reducing social and economic inequalities. Since Independence India has made a significant progress in rural development and In this connection large number of rural development programmes have been implemented by the concerned ministers and departments of the union and state governments in the area of education, health, drinking water, sanitation, transport and communication and supporting infrastructure, among others, have shown varying degree of response and performance at the grassroots level. The present paper is about the rural development programmes which are implemented in the state of Jammu \& Kashmir (J \& K).

\section{ABSTRAK}

Pembangunan pedesaan merupakan konsep holistik yang mencakup pengembangan sumber daya alam dan manusia secara terpadu. Ini bertujuan untuk meningkatkan kesempatan bagi semua orang pedesaan dalam hal kesehatan, pengetahuan, dan pengembangan keterampilan, pendapatan dan partisipasi dalam pengambilan keputusan dan menciptakan lingkungan yang kondusif dalam mengurangi kesenjangan sosial dan ekonomi. Sejak Kemerdekaan India telah membuat kemajuan yang signifikan dalam pembangunan pedesaan dan Dalam hubungan ini sejumlah besar program pembangunan pedesaan telah dilaksanakan oleh menteri dan departemen terkait dari serikat pekerja dan pemerintah negara bagian di bidang pendidikan, kesehatan, air minum, sanitasi, transportasi dan infrastruktur komunikasi dan pendukung, antara lain, telah menunjukkan tingkat respons dan kinerja yang bervariasi di tingkat akar rumput. Makalah ini membahas tentang program pembangunan pedesaan yang dilaksanakan di negara bagian Jammu \& Kashmir (J\&K).
Keywords: Rura Development Programmes, Government, Implementation, Schemes, State 


\section{INTRODUCTION}

Rural development connotes overall development of rural areas with a view to improve the quality of life of rural masses (Singh, 2007). India, since independence has made a significant progress in rural development with an integrated approach towards improving the quality life of the rural poor and by ensuring equality and effective people's participation (Hazra, 2014). Many social scientists, while giving the concept of rural development, have emphasized on effective participation of the rural people in achieving the objective of fuller utilization of available physical and human resources, and thus, higher incomes and better living conditions (Das, 1998). Rural development is an important issue in the country's planning process. Since the beginning of First Five Year Plan in 1951-52, the centre and state governments have launched various rural development programmes from time to time for the overall development of rural areas.

Rural Development Department in Jammu and Kashmir State in fact has come of age through the Panchayati Raj route and has, for last more than two decades, been involved in the implementation of the various Centrally sponsored schemes and the schemes having been carved out by the State government for upliftment of the rural society. Mahatma Gandhi. National Rural Employment Guarantee Scheme (MGNREGS), Sampooran Gramin Rozgar Yojana (SGRY), Swranjayanti Gram Swarozgar Yojana (SGSY), Indira Awas Yojana 
(IAY), Integrated Watershed Development Programme (IWDP) and host of other Centrally sponsored schemes are presently being looked after through Rural Development Department by which rural infrastructure has been greatly strengthened and wage employment to poor and down-trodden strata of the society afforded at their doorstep. The Rural Development and Panchayati Raj in Jammu and Kashmir State thus in the present context emerges to be the sole movement destined to change the face of the rural society (Jammu, 15/01/2016).

\section{Literature Review}

There has been considerable recent discussion of the changes that are taking place in rural development both in terms of the nature of the changes underway within rural economies and in terms of the approaches adopted towards rural policy. The predominant characterisation is of a single change, commonly from an approach focussed fundamentally on the agricultural sector towards one focussed on rural territories and more diversified economic activity (Van der Ploeg et al., 2000; Léon, 2005; OECD, 2006). However, we argue that there has been a more steady process of economic and social change in rural areas over a longer period of time (Hodge and Midmore,2008). 
18 The immediate post-war model centred on the agricultural sector. Increasing food production was a first priority and other objectives, such as enhancing rural employment and services, were seen as following directly from the production support given to the agricultural sector. But through time the approach has changed, shifting to multisectoral, territorial and local approaches. The multisectoral policy recognises the limits to agricultural production support and sees agriculture as one of several economic sectors through which the development objectives can be attained. The focus may still be on farming, but there is encouragement for agricultural diversification. The territorial approach recognises the wider interactions within the rural economy and the importance of social and environmental as well as economic issues. Finally, the differentiation between rural areas and the variation in individual circumstances within areas promotes a search for actions that recognise the specificity of solutions at most local levels. These changes have reflected both forces fundamentally associated with national economic change and other factors more governed by local circumstances. And they have major implications for the methodologies that are relevant for the analysis of rural problems and the evaluation of policies (Hodge and Midmore,2008).

Rural development programmes mainly focuses on poverty elevation, better livelihood opportunities, provisions of basic amenities and infrastructure facilities through innovative programmes of wage and self employment. 
The State of Jammu and Kashmir is, strategically speaking, a prominent State in the Indian Union. The State comprises three divisions namely, Jammu, Kashmir and Ladakh, and for administrative purposes, it has been demarcated into two divisions, i.e., Kashmir and Jammu. As per the census 2011, the population size of $J \& K$ is 12,541302 , rural population is 9108060 i.e. 72.6 percent and Urban population is 3433242 i.e. 27.3 percent. The living conditions of the rural people are very low because of which development of rural areas in the state must receive much attention.

In J\&K Rural Development Department, is working from a long time and aims at developing the rural economy and upliftment of rural masses. It has become an effective tool for reducing the number of people living below poverty line and also narrowed down the income inequalities between haves and the have-nots in rural sector (Govt. of J\&K, 02/02/2015). However, the beginning of the militancy in the State in 1989 shattered the development activities. As a result the development scenario of the state came to a complete halt, which resulted in decline in employment, gross domestic product and per capita income.

\section{Methods}

This paper uses case study approach which offers scope for development of an appropriate evaluative strategy for rural policy. Rigorous in depth study of carefully selected local areas, using a 
mixture of quantitative and qualitative data, can develop a sense of the interaction between increasingly diverse mixes of measures in contrasting rural contexts where different factors influence their expression and impacts, and contribute to understanding of how and why they operate in the way they do (Hodge and Midmore,2008). This centre of interest of multiple case studies, described as a "quintain" by Stake (2006) is of a "contemporary phenomenon in a real-life context, especially when the boundaries between the phenomenon and context are not clearly evident" (Yin, 1994). Therefore, much of the preceding discussion can be related to Yin's strategic recommendations for case study design and implementation. These begin with selection and exploration of the objects of study, on the basis of general suppositions about the impact of policy which require testing. Multiple evidence sources should be scrutinized to test rival hypotheses, which might provide alternative explanations. Common protocols to investigate different expressions of the phenomenon impart additional robustness. Analysis requires assessment of different patterns in the multiple data sources to refine and rule out competing hypotheses, both within individual case studies and between case studies carried out in different contexts (see, for example, Coffey and Atkinson, 1996).

\section{Results and discussions}


From last two decades the state and centre governments have launched a number of State and Central Sponsored Schemes in the areas of Health \& Family Welfare, Education, Employment \& Poverty Alleviation, Agriculture, Women \& Child Development, Sanitation, Housing, Safe Drinking Water, Irrigation, Transport, Tribal Development, Border Area Development, Social Welfare, etc., both in rural and urban areas of the State. The main objectives of all these schemes are to generate wage employment, to provide houses to rural houseless families, to create durable community assets and rural infrastructure, to provide means of self employment to the rural poor through different self employment schemes and to strengthen Panchayat Raj Institutions. The following schemes have been implemented by the $J \& K$ government through rural development department:

\section{Rural Development Programmes in J \& K}

\begin{tabular}{|c|c|c|c|}
\hline $\begin{array}{l}\text { Name of } \\
\text { the prog- } \\
\text { ram }\end{array}$ & $\begin{array}{l}\text { Swarnajyanti } \\
\text { Gram Swarozgar } \\
\text { Yojana (SGSY) }\end{array}$ & $\begin{array}{lr}\begin{array}{l}\text { Mahatma } \\
\text { National }\end{array} & \begin{array}{r}\text { Gandhi } \\
\text { Rural }\end{array} \\
\begin{array}{l}\text { Employment } \\
\text { Guarantee }\end{array} & \text { Act } \\
\text { (MGNREGA) } & \\
\end{array}$ & $\begin{array}{l}\text { National } \\
\text { Health } \\
\text { (NRHM) }\end{array}$ \\
\hline $\begin{array}{l}\text { Objective } \\
\text { s }\end{array}$ & $\begin{array}{l}\text { To ensure a time } \\
\text { bound programme } \\
\text { for bringing a } \\
\text { specific number of } \\
\text { below poverty line } \\
\text { (BPL) families } \\
\text { above the poverty } \\
\text { line through } \\
\text { integrated } \\
\text { approach. }\end{array}$ & $\begin{array}{l}\text { The objectives of the } \\
\text { Act are: } \\
\text { To provide, on } \\
\text { demand, not less } \\
\text { than one hundred } \\
\text { days of unskilled } \\
\text { manual work in a } \\
\text { financial year to every } \\
\text { household in rural } \\
\text { areas. }\end{array}$ & $\begin{array}{l}\text { The objectives of the } \\
\text { mission are: } \\
\text { Reduction in child } \\
\text { and maternal } \\
\text { mortality } \\
\text { Universal access to } \\
\text { public services for } \\
\text { food and nutrition, } \\
\text { sanitation and } \\
\text { hygiene and universal }\end{array}$ \\
\hline
\end{tabular}


.. To create productive assets of prescribed quality and durability through wage employment.

i. To strengthen the livelihood resource base of the rural poor

t. To proactively ensure social inclusion.

i. To strengthen

Panchayat Institutions. access to public

health care services

Prevention and control of

communicable and

non-communicable

diseases

Access to integrated comprehensive

primary health care

Population

stabilization, gender and demographic balance

Revitalize local health traditions

mainstream AYUSH

Promotion of healthy life styles

\begin{tabular}{|c|c|c|c|}
\hline $\begin{array}{l}\text { Target } \\
\text { groups }\end{array}$ & $\begin{array}{l}\text { It targets the } \\
\text { families below the } \\
\text { Poverty in Line } \\
\text { (BPL) in rural } \\
\text { areas constitute } \\
\text { the target group of } \\
\text { the SGSY. Within } \\
\text { the target group, } \\
\text { special } \\
\text { safeguards have } \\
\text { been provided to } \\
\text { vulnerable } \\
\text { sections, by way } \\
\text { of reserving } 50 \% \\
\text { benefits for } \\
\text { SCs/STs, 40\% for } \\
\text { women, 15\% for } \\
\text { minorities and 3\% } \\
\text { for disabled } \\
\text { persons (Gupta, } \\
2003 \text { ). }\end{array}$ & $\begin{array}{l}\text { The Scheme was } \\
\text { introduced in } 200 \\
\text { backward districts of } \\
27 \text { states. } \\
\text { Another } 130 \text { districts } \\
\text { were covered in } \\
2007-08 \text { and all the } \\
\text { remaining districts } \\
\text { would be under the } \\
\text { NREGS in 2008-09. }\end{array}$ & $\begin{array}{l}\text { As many as } 143129 \\
\text { beneficiaries received } \\
\text { cash benefits. It has } \\
\text { identified } 18 \text { States } \\
\text { for special attention. } \\
\text { These are Arunachal } \\
\text { Pradesh, Assam, } \\
\text { Bihar, Chhattisgarh, } \\
\text { Himachal Pradesh, } \\
\text { Jharkhand, Jammu \& } \\
\text { Kashmir, Manipur, } \\
\text { Mizoram, Meghalaya, } \\
\text { Madhya Pradesh, } \\
\text { Nagaland, Orissa, } \\
\text { Rajasthan, Sikkim, } \\
\text { Tripura, Uttaranchal } \\
\text { and Uttar Pradesh. }\end{array}$ \\
\hline $\begin{array}{l}\text { Implemen } \\
\text {-tation }\end{array}$ & $\begin{array}{l}\text { The SGSY } \\
\text { scheme is being } \\
\text { implemented in } \\
\text { the state by the } \\
\text { District Rural } \\
\text { Development } \\
\text { Agency (DRDA) in } \\
\text { accordance with } \\
\text { the guidelines of } \\
\text { Government of } \\
\text { India. } \\
\text { SGSY is now }\end{array}$ & $\begin{array}{l}\text { Schemes like NREGS } \\
\text { and Hariyali are } \\
\text { highly relevant for the } \\
\text { State because of the } \\
\text { rising soil degradation } \\
\text { and low levels of } \\
\text { water conservation. } \\
\text { Employment } \\
\text { generation increased } \\
\text { from } 40.04 \text { percent } \\
\text { from the year 2008- } \\
09 \text { to } 66.80 \text { percent }\end{array}$ & $\begin{array}{l}\text { NRHM was } \\
\text { launched in April } \\
\text { 2005. J\&K has } 1907 \\
\text { sub-centres (SCs), } \\
396 \text { primary health } \\
\text { centres (PHCs), } 84 \\
\text { community health } \\
\text { centres (CHCs), } 845 \\
\text { doctors at PHC's, 173 } \\
\text { Specialists at CHC's, } \\
867 \text { nursing staff at } \\
\text { PHC's and CHC's }\end{array}$ \\
\hline
\end{tabular}




\begin{tabular}{|c|c|c|c|}
\hline & $\begin{array}{l}\text { renamed } \\
\text { NRLM. }\end{array}$ & $\begin{array}{l}\text { up to the year 2012- } \\
13 \text { but showed drastic } \\
\text { decrease of } 30.15 \\
\text { percent during the } \\
\text { year } 2013-14 \\
\text { (Mehraj-ud-din, } \\
\text { et.al.,2015). }\end{array}$ & $\begin{array}{l}\text { (ibid, GOI, 2005). To } \\
\text { promote institutional } \\
\text { deliveries } \\
\text { benefits are being } \\
\text { provided to the } \\
\text { mother beneficiaries } \\
\text { in rural and urban } \\
\text { areas under Jannai } \\
\text { Suraksha } \\
\text { (JSY). Yojana } \\
\end{array}$ \\
\hline $\begin{array}{l}\text { Imple- } \\
\text { menting } \\
\text { Agency }\end{array}$ & $\begin{array}{l}\text { The SGSY will be } \\
\text { implemented by } \\
\text { the DRDAs } \\
\text { through the } \\
\text { Panchayat } \\
\text { Samitis. The } \\
\text { process of } \\
\text { planning, } \\
\text { implementation } \\
\text { and monitoring } \\
\text { would integrate } \\
\text { the banks and } \\
\text { other financial } \\
\text { institutions, the } \\
\text { PRls, NGOs as } \\
\text { well as technical } \\
\text { institutes in the } \\
\text { districts. }\end{array}$ & $\begin{array}{l}\text { The NREGA was } \\
\text { extended to the State } \\
\text { in } 2007 \text { and the } \\
\text { guarantee component } \\
\text { in terms of } \\
\text { unemployment } \\
\text { allowance has been } \\
\text { made operational. } \\
\text { The primary } \\
\text { objective of the Act is } \\
\text { meeting demand for } \\
\text { wage employment in } \\
\text { rural areas. The Act is } \\
\text { an important vehicle } \\
\text { for strengthening the } \\
\text { democracy in the } \\
\text { country (Kumar, } \\
\text { 2013). }\end{array}$ & $\begin{array}{l}\text { No doubt NRHM has } \\
\text { made a significant } \\
\text { impact on health care } \\
\text { delivery in state. } \\
\text { However, it is short of } \\
\text { achieving its goal. } \\
\text { There are several } \\
\text { challenges in its } \\
\text { implementation. } \\
\text { There is need to } \\
\text { strengthen systems to } \\
\text { monitor and audit } \\
\text { performance and } \\
\text { health indices. this } \\
\text { will allow for course } \\
\text { corrections in process } \\
\text { of implementation of } \\
\text { NHRM. }\end{array}$ \\
\hline
\end{tabular}

\begin{tabular}{|c|c|c|}
\hline $\begin{array}{ll}\text { Name of } \\
\text { the } \\
\text { program }\end{array}$ & Indira Awaas Yojana (IAY) & $\begin{array}{l}\text { Pradhan } \quad \text { Mantri } \text { Gram } \\
\text { Sadak Yojana (PMGSY) }\end{array}$ \\
\hline Objectives & $\begin{array}{l}\text { The objective of the } \\
\text { Indira Awaas Yojana is primarily } \\
\text { to help construction/upgradation } \\
\text { of dwelling units of members of } \\
\text { Scheduled Castes/Scheduled } \\
\text { Tribes, freed bonded labourers, } \\
\text { minorities in the below poverty line } \\
\text { category and other below poverty } \\
\text { line non-SC/ST rural households } \\
\text { by providing them a lump sum } \\
\text { financial assistance (vide } \\
\text { Ministry's order No.L- } \\
\text { 11019/2/2006-RH dt. 08/02/2007). }\end{array}$ & $\begin{array}{l}\text { The primary } \\
\text { objective of the PMGSY is to } \\
\text { provide Connectivity, by way } \\
\text { of an all-weather Road, to } \\
\text { the eligible unconnected } \\
\text { habitations in the rural areas } \\
\text { with a population of } 500 \\
\text { persons and above in Plain } \\
\text { areas. }\end{array}$ \\
\hline
\end{tabular}




\begin{tabular}{|c|c|}
\hline $\begin{array}{l}\text { Target } \\
\text { groups }\end{array}$ & $\begin{array}{l}\text { Like other parts of the } \\
\text { country, IAY was launched in } \\
\text { Jammu and Kashmir during the } \\
\text { year } 1985-86 \text { and covers all the } \\
\text { districts of the State. In Jammu } \\
\text { and Kashmir, the Indira Awaas } \\
\text { Yojana is being implemented by } \\
\text { the Department of Rural } \\
\text { Development. The two divisions of } \\
\text { the State (Kashmir and Jammu) } \\
\text { have separate Directorate of Rural } \\
\text { Development. While the } \\
\text { Directorate of Rural Development, } \\
\text { Kashmir is responsible for } \\
\text { implementing the scheme in } \\
\text { Kashmir province including the } \\
\text { two districts of Leh and Kargil, the } \\
\text { Directorate of Rural Development, } \\
\text { Jammu implements the scheme in } \\
\text { Jammu province. }\end{array}$ \\
\hline $\begin{array}{l}\text { Implementa } \\
\text { tion of IAY } \\
\text { in J\&K }\end{array}$ & $\begin{array}{l}\text { At the block level the } \\
\text { scheme is implemented by the } \\
\text { Department of } \\
\text { Development, through the Block } \\
\text { Development Offices. Each Block } \\
\text { Development Officer is assisted } \\
\text { by the Planning Officer, } \\
\text { Panchayat Secretaries, Assistant } \\
\text { Executive Engineer, Junior } \\
\text { Engineers, Village Level Workers } \\
\text { (VLW) and Multipurpose Workers } \\
\text { (MPW). At the village level, the } \\
\text { Village Panchayats Committees } \\
\text { help the VLW in identifying the list } \\
\text { of potential IAY beneficiaries }\end{array}$ \\
\hline
\end{tabular}

In respect of the Hill States

(North-East, Sikkim,

Himachal Pradesh, Jammu \&

Kashmir and Uttarakhand),

the Desert Areas (as

identified in the Desert

Development Programme),

the Tribal (Schedule V)

areas and Selected Tribal

and Backward Districts (as

identified by the Ministry of

Home Affairs and Planning

Commission) the objective

would be to connect eligible

unconnected habitations with

a population of 250 persons

and above (PMGSY, 2013).

\section{PMGSY is a $100 \%$ Centrally}

Sponsored Scheme and has

been implemented in J\&K as

in other parts of India. Since

inception of the scheme and up to the year 2011-12, a

total of 1,777 habitations

have been cleared for connecting with an Allweather road by constructing $7,011 \mathrm{~km}$ of road length. Against this, the State has connected 1,042 habitations by constructing $2,973 \mathrm{~km}$ of road length. The project proposals of the value of Rs. 3,706 crore have been sanctioned to the State of Jammu \& Kashmir till May, 2012 against which Rs. 1,901 crore has been released so far. Out of this, the State has utilized Rs. 1,556 crore.

As per the NFHS-2, around 6 percent of the households in Jammu and Kashmir live in houses that are katcha (made of mud, 
thatch, or other low quality material), 58 percent live in semi-pucca houses (using partly low quality and partly high quality materials), and 36 percent live in pucca houses (made with quality materials throughout, including the roof, walls and floor). Across regions, the percentage of households living in pucca houses is 34 percent in Kashmir region and 38 percent in Jammu region in J\&K. The mean number of persons living per house in Jammu and Kashmir is 2.4 as compared to 2.7 for the country as a whole. The mean number of persons per room is 1.7 in urban areas and 2.3 in rural areas. Condition of the houses in the J\&K State is more pathetic in the rural areas than in urban areas. Sixty percent of the households in urban areas live in pucca houses, as compared to 27 percent of households in rural areas. Around 73 percent of rural households live in semi- pucca or katcha houses as against 34 percent in urban areas.

The NFHS-3 has shown marginal improvement in the housing situation in the state between 1998 and 2006. As per the NFHS-3, 50 percent of the households in Jammu and Kashmir live in pucca houses, 34 percent live in semi-pacca houses and only 11 percent have katcha houses. The mean number of persons living per house in Jammu and Kashmir in 2005-2006 was 2.9 as compared to 3.3 for the country as a whole.

Taking the problem of houseless seriously, Government of India with a view to provide houses to the Scheduled Castes, Scheduled Tribes and Freed Bonded Labourers living below poverty 
56 line, launched Indira Awaas Yojana (IAY) as a component of Rural Landless Employment Guarantee Programme (RLEGP) (GOI, 2009)

\section{CONCLUSION}

In short, rural development aims at all round development of rural economy with more, emphasis on socio-economic amelioration of rural people. The rural development programmes occupy prominent place both in the centre as well as state's economic planning. Without the upliftment of rural masses we can accelerate the pivot of overall Socio-economic development. These programmes work for various components of rural development including generation productive assets and skill, employment generation, improving health facilities, sustainable livelihood enhancements, empowering rural women, fostering social equity and social security. But none of the component may be achieved without proper participation of the people. The main objective of the rural development programme is to raise the economic and social level of the rural people and it's time for the people to realise this and participate in the development work for the same. With the implementation of various state and centre sponsored schemes lot of improvement has been taken place in the overall development of the $J \& K$ state, but still lot has to be done. Thus rural development must be given the top most priority in our planned efforts as maximum population of our country lives in rural areas. 


\section{REFERENCES}

Advani M, Akram M. (2007): 'Health Concerns in India' in Akram's (ed.) Health Dynamics and Marginalized Communities, Jaipur: Rawat Publications, p. 03-26.

Coffey A., Atkinson p. (1996). Making Sense of Qualitative Data. Thousand Oaks, CA: Sage.

Das, P.K. (1998): 'Poverty Alleviation in India', Kurukshetra, August.

GOI (2009): Evaluation report on Indra Awas Yojana, Jammu and Kashmir, Programme Evaluation Organisation, Planning Commission Government of India, New Delhi: Feb.

GOI (2010): Evaluation study on Rural Roads components of Bharat Nirman programme, Evaluation Organisation Planning Commission, New Delhi: May.

GOI (2013-14): Evalution study of indra awas youjna, planning comission Govt of India, New Delhi.

GOI (2005) Report M inistry of Health and Family Welfare.

Gupta, K.R.(2003): 'Rural Development in India', Delhi: Atlantic Publishers and Distributors, Vol. 1.

Hazra, Anupam (2014): 'The Saga of Boosting Rural Development in India', Kurukshetra, Vol. 62: No. 4, p. 24.

Hodge, lan et Peter Midmore Models of Rural Development and Approaches To Analysis Evaluation And Decision-Making, 307, September-October 2008: Nouvelles frontières entre les politiques rurales en Europe

Jammu \& Kashmir (2009): Evaluation Report on Swarnajyanti Gram Swarozgar Yojana (SGSY), Programme Evaluation Organisation Planning Commission Government of India, February.

Kumar, Ritu Naresh (2013): Rural Development in India: A Brief Discussion Sanshodan Kranti, Vol. 9: Issue- I, December.

Mehraj-ud-din, Wani, Nazia, Khan, Imran Ahmad (2015): Performance of MGNREGA in J\&K, International Journal of Innovative Research and Development, Vol.4: issue 1.

PMGSY programme guide line (2013): Substituted vide Circular No. P17025/39/2010-RC dated 10/3/201). 
Rao, Kankipati Srinivasa \& Kumar, V.D Santosh (2015): 'Rural Development Budget 2015-16: An Overview', Kurukshetra, Vol. 63: No.06, p. 5.

Sen A. (2006): 'Why Health Equity?' in Anand S, Peter F, Sen A (ed.) Public Health Ethics and Equity, New Delhi: Oxford University Press, pp. 1718.

Singh Katar (2007): 'Rural Development: Principles, Policies and Management', New Delhi: Sage Publication.

Govt.of J\&K, Directorate of Rural Development, http://drdk.nic.in/catagories.html accessed on 02/02/2015.

Jammu,http://jammu.gov.in/departments/rural-development.htm accessed on 15/01/2016.

Vide Ministry's order No.L-11019/2/2006-RH dt. 08/02/2007.

Yin R.-K. (1994). Case Study Research. CA, Sage, Thousand Oaks. 